\title{
PECULIARITIES OF CONVEYING THE STRUCTURAL AND SEMANTIC SPECIFICITY OF JAPANESE ONOMATOPOEIA IN TRANSLATION OF TEXTS OF ADVERTISING CHARACTER
}

\author{
Andrii Medvediv, \\ Minneapolis, USA, \\ e-mail: amedvidiv@gmail.com
}

\author{
Anna Dmytruk, \\ Ivan Franko National University, \\ Lviv, Ukraine, \\ e-mail: dzihikosan@gmail.com
}

Received March, 4, 2019; Accepted May, 16, 2019+

\begin{abstract}
It historically happened that onomatopoeia of the Japanese language is the most commonly used lexical group for writing advertisement texts. Onomatopoeic words, firstly, affect the background knowledge of a Japanese consumer at the phonetic level and touch their consciousness as effective as possible, and, secondly, they meet the main tasks of advertising: to formulate clearly and concisely, to accentuate, and to cause the desired reaction. Advertising texts belong to communicatively meaningful stylistic subsystems of any language and, therefore, play a significant role in the study of the most used elements of a certain lexical stratum. This article deals with the problem of translation of onomatopoeia, which is used in the Japanese texts of advertising character, as one of the most informative types of linguistic material of colloquial and everyday style. The main factors governing the choice of English counterparts of the Japanese onomatopoeia employed in advertising for conveying the specificity of the national and cultural semantics which this vocabulary possesses have been considered. Using the examples of gitaigo and giongo onomatopoeia collected on the basis of contemporary Japanese advertising texts, an attempt has been made to investigate the most accurate ways of translation of an onomatopoeic word as a bright national and cultural semantic unit of the Japanese language. Having analyzed the onomatopoeic words of the chosen advertisements, we have established that the stylization as gitaigo causes a translator the greatest difficulty. The repetitive morphemes, of which these onomatopoeias are composed, most often can be translated descriptively only, in the way which is most appropriate in a given context, or in the way of semantic transformation.

Key words: Japanese language, onomatopoeic vocabulary, lexeme, seme, semantic meaning, contextual translation, semantic transformation.
\end{abstract}

\section{Introduction}

A characteristic feature of modern linguistics is the orientation on study of the semantic structure of a word. This process involves the study of a language as a tool of representation of nature of the human mind. One of the main theories of the origin of a language, as it is known, is the hypothesis of imitation of sounds, which was founded 
by Democritus and Plato. According to this hypothesis, a language started to exist due to imitation by a human being of other objects or sounds in nature. Vocal sounds in the imitation of natural sounds can gain symbolic meaning. The existence of this connection between a sound and a symbolic meaning was recognized by G. W. Leibniz, J. G. Herder, W. Humboldt, and others. In linguistics, this

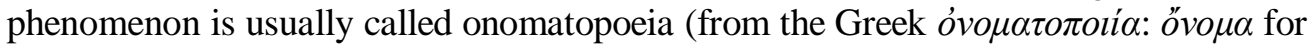

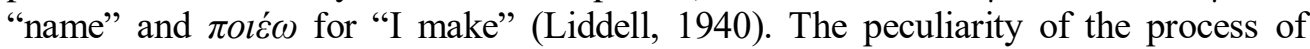
onomatopoeia consists in the fact that in different languages of the world it occurs in different ways. Due to a language's own phonetic inventory, each language has distinct onomatopoeia for the same natural sound. The semantic, functional, and syntactic unity is what the onomatopoeic words naming the same notion in different language systems have in common.

The notion of onomatopoeia in the Japanese language covers many more lexical units than it does in the Indo-European languages. Moreover, onomatopoeia remains one of the most productive means of generating new words in contemporary Japan, since accidentally created onomatopoeias subsequently enter the general language (Kozub, 2006: 31). Sound imitative words appear in the life of a Japanese person since the very childhood from the texts of comic-manga (漫画, おばあちゃ $ん)$. Japanese onomatopoetic lexis is quite widely represented in the texts of advertising character, which are intended to meet the information needs of the population, and on the basis of which the communicative potential of one or another type of lexis is determined.

The purpose of this article is to carry out structural and semantic analysis of the used onomatopoeic units in the selected material of Japanese texts of advertisement and to identify the functional and syntactic aspects of their use in order to adequately translate them into another language as well as to establish the most effective methods of conveying the semantics of Japanese onomatopoeic words to the readers.

Active study of onomatopoeia as a linguistic phenomenon began in Japan only in the second half of the XX century. By this time, Japanese linguists dealt mainly with textological investigations. The first finding of the origin of Japanese onomatopoeic lexis, the attempts of its classifying, as well as the development of issues of sound symbolism in the Japanese language in general are found in the works of the first half of the XX century by the Japanese linguists such as Ando Mazattu (安藤 正次), Arisaka Hideyo (有坂 秀世), Jindo Kaku (神保 格), Ishiguro Roheya (石黒 鲁平), Kikudzava Sueo (菊澤 季生), Kindaichi Kyosek (金田一 京助), Onisha Masao (大西 雅雄), Sakum Kanay (佐久間 鼎) and others. We should mention the fundamental work by Suzuki Akira "Theory of the Origin of Language", where the author highlights the main ways of deriving a language: imitation of animal voices, imitation of human voice, imitation of sounds of nature, the description of the actions and states. In the second half of the XX century, under the influence of European linguistics, a large number of lexicographic works are already precisely dedicated to the study of onomatopoeic lexis as the materialization of the phenomenon of onomatopoeia directly in a language. Here it is worth mentioning the names of S. Hattori (服部), H. Kindaichi (金田一), S. Murayama (村山), K. Inoue (井上) and others, who conducted the first complex generative studies of the Japanese language.

As for modern Japanese researchers in the field of onomatopoeia, first of all, we should mention the names of such famous experts: Amanuma Yasushi, Asano 
Tsuruko, Atoda Toshiko, Kindaichi Haruhiko, Ono Masahiro, Tamori Ikuhiro, Uchida Hiroshi, Hinata Shigyo, Hoshino Kadzooko, Chang Andrew S., Yamaguchi Nakami, Naoyuki Osaka, Hiroko Inose, Susumu Uemura and others. These linguists not only investigate onomatopoeia as an object of purely scientific interest, but also have created a number of interpretative and bilingual dictionaries of the onomatopoeic lexis of the Japanese language (see: Amanuma, 1974; Asano, 1985; Asano and Kindaichi, 1988; Atoda and Hochino, 1995; It, 2007; Osaka, 1990; Tamori, 1991; Uchida, 1996; Uemura, 2010; Hinata, 1991; Yamaguchi, 2003; Inose, 2008, Chang, 1990).

Recently, interest in the problem of onomatopoeia in Japanese can be traced in the studies of Ukrainian linguists. Among the complex studies of the onomatopoeic system of the contemporary Japanese language, there can be distinguished the works of L. Bohdan, O. Kobelyanska, V. Migdal'skaya, V. Migdal'sky and others. However, the stratum of onomatopoeic vocabulary, presented in the texts of the advertising character, in our opinion, requires more extensive study as vivid expression of the peculiarity of Japanese national culture. In this work, on the basis of onomatopoeic words used in materials of contemporary advertising texts by means of lexical-semantic and structural analyses an attempt was made to investigate the most accurate ways of translation of an onomatopoeic word as a bright national and cultural semantic unit of the Japanese language.

\section{The role of onomatopoeia in creating Japanese texts of advertising character}

The imitative words compose a significant stratum of the entire lexical structure of the contemporary Japanese language. This is evidenced by the fact that, having 2.500 key items of total contents, the "Dictionary of basic Japanese vocabulary for foreigners" includes in its main register 81 onomatopoeia, i.e., almost $3.3 \%$ of the total amount of lexis referred to the active vocabulary of foreigners, who study Japanese (Kobelyanska, 2017: 166). This fact emphasizes the importance of studying this linguistic phenomenon by foreigners eager to master Japanese speech perfectly.

Distinct in the theories of the origin of onomatopoeic words they keep to, many scholars are unanimous in their opinion that this lexical layer remains the most difficult to master by foreigners.

"The problem is not in writing or reading any of the language units, as in the case of hieroglyphics. Here we face a task of a different level. The associative thinking of the Japanese and a foreigner do not coincide. What is obvious for the first one, very often for the other means absolutely nothing. The Japanese say that in the study of onomatopoeia they cannot act automatically" (Maslov, 1987: 46).

In addition to children's literature, onomatopoeic words in Japan are most often used in colloquial language (3-4\% of the total composition of lexical units of this stratum) and in advertising texts (2-2.5\%) (Kobelyanska, 2017: 162). If the American and European schools of writing texts of advertisement, in general, are similar, the Japanese manner of its writing has a number of unique features. 
In Japanese advertisement, the main stress should be laid on very image. Firstly, such intention, above all, is implemented by the special structure of a sentence. Ellipsis is the most popular structure of the sentence of Japanese advertising, which gives the text more precision and expressiveness (Podshibyakina, 2003: 36). Secondly, for the text of advertising the selection of linguistic units with pronounced national and cultural semantics is carried out.

"By appealing to the background knowledge of the addressee, they (these words) contribute to a more effective influence on the consumer's consciousness" (Mamontov, 2002: 62).

This very role is played by Japanese onomatopoeic words. And finally, it is believed that the Japanese advertisement has clearly expressed relations with a much more ancient Japanese genre with haiku (俳句, はいく). This verse in one to three phrases is extremely vivid and beautiful. Haiku in English often appears in three lines to parallel the three phrases of Japanese haiku.

"This kind of verse is entirely based on symbolism. The Japanese know how to read between the lines very well, and viewers can imagine a whole action just by an image" (Tangeit, 2015: 71).

The specifics usually recede into the background. The Japanese rarely speak directly in their commercials or ad leaflets about discounts, and super-low prices.

\section{Structural features of onomatopoeia in advertising texts}

The main formal criterion in the Japanese language for referring a lexeme to the onomatopoeic class is its morphemic structure, namely, the root reduplication, which greatly enhances the imagery and metaphoricity of these words (Korshikova, 1987: 93).

Thus, in advertising texts you can easily find root reduplication, e.g.:

・ボディソープ。うるおいのある、すべすべ素肌に仕上げます(Kracie).

[Bodisoupu. Uruoi no aru, subesube suhada ni shiagemasu].

"Soap for the body. Moisturizing, making the skin surface smooth".

Quite often, especially in the advertising in the field of cosmetology, instead of entire root reduplication, there is only a doubling of consonants:

・うるおい浸透マスク (超しつとり) (Kracie).

[Uruoi shintou masuku (chou shittori)].

"Moisturizing mask (ultra moisturizing)".

It should be noted here that tissue moisturizing face masks, which are gaining rapid popularity in the whole world, are one of the main elements of skin care in Asia and they have been used in Japanese cosmetology for more than one hundred years. By using the onomatopoeias すべすべ [subesube] (smooth) and しつとり [shittori] (moisturizing), the advertisement attracts the consumer's attention to this feature of the cosmetic product, working at the phonetic level.

Let us remind that traditionally all of the sound imitation words in the Japanese language can be divided into three groups: giseigo, giongo and gitaigo (Dmytruk, 2016: 125). Giseigo is a voice-reproducing word that usually conveys the voices of 
living beings. Giongo is a sound reproducing word that imitates the sounds of abiocoen. Gitaigo is a sound imitative word intended to translate figuratively or symbolically a certain state or its change, phenomenon, character of action by means of linguistics. It should be noted that some scholars indicate the words describing psychological states or bodily feelings as a separate class of onomatopoeia - gijōgo. We consider them to be similar to onomatopoeia representing a concept mimetically and performatively rather than referentially. As for advertising texts, it is difficult to determine in which cases giongo and gitaigo should be recorded in katakana (片仮名, かたかな) and in which cases they are to be in hiragana (平仮名, ひらがな) because those texts are composed according to the subjective individual preferences of their authors. An important role is played by the main idea of the text. Let us give an example of advertising text, in which one onomatopoeic word is written both in katakana and in hiragana:

・さくさくばんだ。サクサクビスケットとミルクチョコ!(Kabaya)

[Sakusaku panda. Sakusaku bisuketto to miruku choko!]

"Crispy Panda. Crispy cookies with milk chocolate!"

In this example, the main quality of the product is highlighted by means of onomatopoeia sakusaku (crispy) written in hiragana さくさく and in katakana サクサ $ク$ in the same advertisement. And let us determine the reasons of usage of the image of a panda in this example and in advertising in general. In Japanese culture, there is a cult of all "cute". It means "attractive", but not in the sense of classical canonical beauty, but in the sense of enjoyment of looking at a certain image. The clumsy panda, which is constantly tumbling, standing with difficulties on its four feet, is a favorite of Japanese children due to its similarity to a teddy bear. Therefore, this image is very common in the field of making sweets, in the haberdashery industry, and in cosmetology.

It should be noted that, as a rule, part of the text containing giongo and gitaigo is placed rather non-standard: for example, diagonally, along, and upside down. You can also observe the following features of designing of advertising texts as highlighting it in a large font or in other colors, the use of nonstandard spelling fonts (Dmytruk, 2016: 126).

Quite often, especially in the sphere of food products advertising, you can see the stylization of words as gitaigo. Here is an example:

- POCKYつぶつぶいちご(Pocky).

[POCKY tsubutsubu ichigo].

"POCKY with grainy strawberries".

The onomatopoeia つぶつぶ [tsubutsubu] is created by reduplicating the word 粒 [tsubu] (grain, drop). There is no such a term in the current Japanese Onomatopoeia dictionaries. It is created situationally for this advertisement. However, according to its reduplication structure and ability to represent a concept mimetically and performatively, it can be attributed to the onomatopoeic class of the Japanese language. To translate this ad, we should know some additional information about Japanese stick-like biscuits 'POCKY', which can be truly called national sweets. They consist of biscuit sticks, which earlier were coated only with chocolate. The almond and strawberry coatings appeared after chocolate ones. Today, the product line includes dairy, caramel, green tea, honey, banana, creamy and coconut flavored coatings and also thematic products such as "Decorated POCKY" with colorful decorative stripes in the coating, "Men's POCKY" with dark 
bitter chocolate and "POCKY for adults". It is not surprising that the name for such popular sweets has been given by onomatopoeic word ポッキン [pokkin] (sound of breaking stick). In our case, biscuit sticks are coated with the strawberry coating with grained pieces which should be conveyed in translation.

These are the general structural features of the onomatopoeia of Japanese advertising art. What are the semantic peculiarities of these linguistic units and what means are used to translate their pronounced national and cultural semantics?

\section{The ways of conveying semantic features of onomatopoeia of Japanese advertising texts into another language}

One of the characteristic features of the Japanese onomatopoeia is the presence in a single lexeme of several elements of meaning (semes), not all of which can be adequately conveyed in translation. Therefore, when there are several components in a unit of meaning, in translation one can use only the meaning that is appropriate in the given context. The contextual translation is intended to preserve figurative components of meaning that are relevant when reproducing the functionally-syntactic role played by the onomatopoetic unit in a particular advertisement.

The introduction of onomatopoeic words into a text is caused not so much by objective linguistic laws, but by subjective individual preferences of the authors of the corresponding texts- specialists in the field of advertising and journalists. Accordingly, we consider all semantic meanings of the selected and classified by the structural peculiarities of the onomatopoeic words from the advertising texts of various branches and the ways of their translation.

\section{Group of onomatopoeia with root reduplication}

1. どんどん [dondon] has several meanings, one of which, with and without the particle と [to]- "rat-tat", "boom-boom”, “chop-chop". The unit どんどんする [dondonsuru] has the meaning "knock, hit". However, without any particles it has the following meanings: "quickly"; "smoothly"; "always", "often”, "constantly". Examples:

(Ameba).

・ガルオクで可愛いアイテムをゲットして、どんどんコーデしちやお

[Gareokude kawaiiaitemuwo gettoshite, dondon koude shichao].

"Gain a nice thing at Garuoku, it will always fit to many things".

・瘦せた分だけどんどん得をする(Ameba).

[Yaseta bun dake dondon toku o suru].

"You have just to lose weight-and you will get a quick profit".

2. ふわふわ [fuwafuwa] has meanings, which are used with and without the particle と [to]: "easily, unsteady"; "with ease" (implemented when used with words indicating movement in the air or on the water); "in vain", "uselessly" (about the time); "unstable"; "volatile, changeable". The following meaning that can be used with the particle の [no] and without anything - "light, airy, fluffy". The meaning with the use of particle に [ni] -“easy”; “fine”. The meaning of the word ふわふわ している [fuwafuwashite] is "be light, airy, fluffy". In the following examples, in the analyzed onomatopoetic word the following meanings are realized -"light, airy, 
fluffy". In the context of the first example, the "light" will suit the best. And in the second and third examples, "air" will do. Examples:

・ふわふわシュッワッ! ! 不思議フーセンガム!(Meiji).

[Fuwafuwa shuwwa! Fushigi fuusen gamu!]

"Airy pop rock! Amazing chewing gum!"

・ふわふわしっとり新ファンデーションエクサージュ (Ameba).

[Fuwafuwa shittori shin fandeeshon ekusaaju].

"A light moisturizing new base for make-up "EXAGE”.

・ねるねるねるねねっておいしいふわふわおかし(Kracie).

[Nerunerunerune nette oishii fuwafuwa okashi].

"Kneaded sweet candy "Nerunerunerune".

As we have seen from the example of the onomatopoeia nerunerunerune, in a number of cases, a triple duplication of a morpheme occurs, which is called a triplication resulting in triads.

3. すいすい [suisui]. This word can be used with the particle と [to] and it means "fast, easily"; "smoothly", "without obstacles". Example:

すいすい入る $(B I G L O B E)$.

[Suisui iru].

"Easily absorbed".

4. ぐんぐん [gungun]. This onomatopoeic word has the following meanings: "steadily"; "actively", "vigorously" (implemented with words that mean "movement", "development", "change"). Example:

ぐんぐん潤う $(A W A K E)$.

[Gungun uruou].

"Actively moisturized".

5. ブルブル [buruburu]. The first meaning is “a sound of vibrations" (as if created by a motor). In the following meanings can be used with the particle $と$ [to] "noisy, loudly"; "trembling", "vibrating".

In Japanese society, there is a cult of beauty. A woman's face is no exception. In this country, there are a lot of strange for Europeans tools designed to maintain beauty of different parts of a face: nose, jaws, ears and others. Actually advertising one of such devices we are going to present: nose straightener (see Fig. 1). Example:

ブルブル振動で鼻を刺激。すっきり美鼻(Taobao).

[Buruburu shindou de hana o shigeki. Sukkiri bihana].

"With vibration oscillations, they change a nose. The straight and beautiful nose".

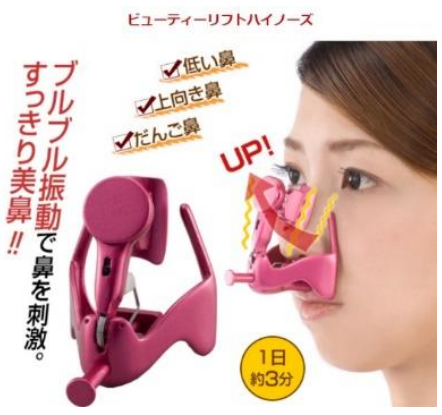

Figure 1. Taobao 
1. くるくる [kurukuru]. The word has several meanings. The first meaning is "around"; "in circles"くるくるした [kurukurushita] "circular"; "twisted". Being combined with the word 回す [mawasu] "to twist" it has the meaning "rotate", "twist", "spin". In a combination with the word 動 < [ugoku] "move"; "work" (about the mechanism), it means "move in a circle"; "rotate". Examples:

・くるくるたこやき(Kracie).

[Kurukuru takoyaki].

"Twisted takoyaki".

Takoyaki is a popular dish in Japan, made of liquid dough and a piece of octopus, fried on a special pan with hemispherical holes.

• くるくるワッフル(Rakuten).

[Kurukuru waffuru].

"Twisted Waffles".

2. わくわく [wakuwaku] has the following meanings: "hope"; "being excited"; "exciting"; "touching". The meaning わくわくした [wakuwakushita] "get excited", "get nervous"; "be awaken"; "be admired". Example:

わくわくどうぶつ。ソフトキャンディ(Rakuten).

[Wakuwaku doubutsu. Sofuto kyandi].

"Exciting animals. Soft candy".

3. ぷりぷり [puripuri] has the following meanings: "trembling", "shivering"; “angrily, wrathfully”. ぷりぷりする [puri purisuru] means "get angry”, "get fury”, "fly into a rage". Example:

ぷりぷりプリンろスリー(Heart).

[Puripuri purin 3 surii].

"Three purins trembling" (see Fig. 2).
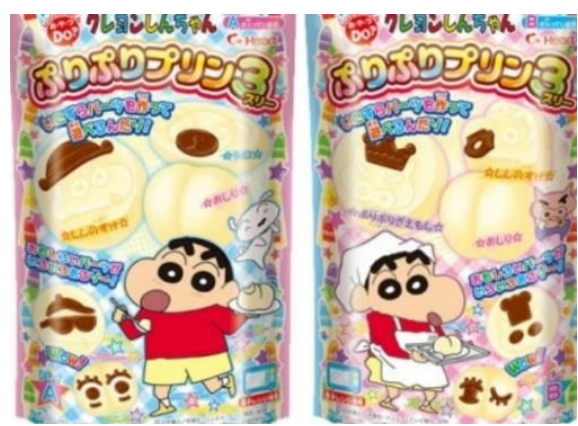

Figure 2. Heart

Purin is cream-caramel or custard pudding. This very kind of purin is advertised in the form of a baby's butt. It should be noted that in Japanese culture, unlike the European, there is no taboo on some parts of a human body. For them, such topics are generally accepted and are not a reason for shame.

4. ぷちぷち [puchipuchi]. The analyzed word has the following meanings: a sound when a bubble bursts (or another small object); "small pieces"; "small grains"; "feeling lumps" (for example, in food); "bubble wrap". Example:

おえかきシャーベット。 
ぷちぷちでカラフルにおえかきしよう!(Rakuten).

[Oekaki shaabetto. Puchipuchi de karafuru ni oekaki shiyou!]

"Painting with sherbet. Let's draw colored paintings by bubbles!

5. さくさく [sakusaku] means "crispy"; "layered". さくさくする [sakusakusuru] has meanings "be crispy"; "be fragile"; "be not juicy". Example:

CRUNKY サクサク感がギッシリ!(Rakuten).

[CRUNKY sakusaku kan ga gisshiri!]

"CRUNKY" is filled with a crispy sense!"

6. キラキラ [kirakira]. The analyzed word has the following meanings: "flash", "glare"; "sparkling", "shine"; "blinking", "flashing", "flickering". The meaning of きらきらする [kirakirasuru] is "shine"; "glitter", "sparkle". Example:

お子さまに大人気のランドセル。リボン\&ティアラの刺紼に、キラキ ラのラインストーンがとってもキレイ! (LOWYA).

[Okosama ni daininki no randoseru. Ribon\&Tiara no shishuu ni, kirakira no rainsutoun ga tottemo kirei!]

"A popular portfolio for a child - randoser. Very beautiful brilliant rhinestones in ribbons and tiaras embroidery!"

Portfolios randoser is a separate topic for our talk, it is impossible not to stop at which when discussing the national and cultural features of Japan. With these portfolios, all children in Japan go to an elementary school. These portfolios are made so qualitatively that they cannot be torn for all their use during six years of elementary school (see Fig. 3).

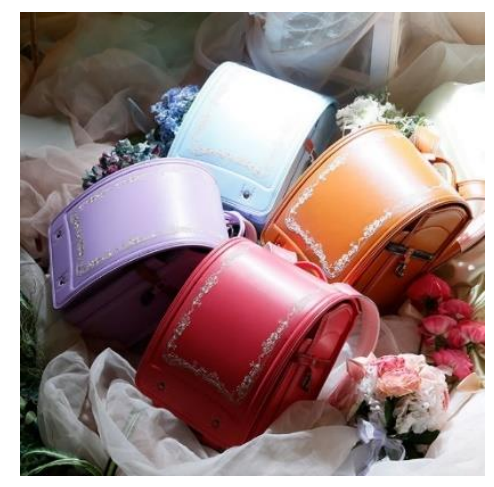

Figure 3. LOWYA

7. しょぼしょぼ (shoboshobo) has the following meanings: "gently", "softly"; "carefully". The unit しょぼしょぼした (shoboshoboshita) has the meaning of "look weak, sick". In combination with the word 目 (me) "eye"; "vision"; "view" it means "misty-eyed gaze", "blurred gaze". Example:

アイケアセット。TV\&スマホのダメージでつらい違和感しょぼしょぼ にトリプルケアで輝く瞳に(Rakuten).

[Ai kea setto. TV\& sumaho no dameeji de tsurai iwakan shoboshobo ni toripuru kea de kagayaku hitomi ni].

"A set for eye care. Triple gentle care against painful discomfort caused by long watching the TV and smartphone. Result - your pupils are shining!" 
Healthy eyes are one more subject of daily care of the Japanese. It is not a secret that many Japanese have poor eyesight, but prefer contact lenses instead eyeglasses, which in their opinion are uncomfortable and inconvenient. Therefore, their eyes should be constantly moisturized and, therefore, the nearly each Japanese in his bag has a little bottle of eye care. These drops help people with strong eyes too after a long working day and help them to bring their exhausted for the long working day eyes to the norm.

8. さらさら [sarasara] has the following meanings: "easily, with ease"; "liquid", "flowing"; "smooth", "flat"; "soft", "gentle". It is also peculiar to it the meaning with and without the use of the particle と [to]: "gurgling", "with gurgling"; "with rustling"; "with a buzzing". The meaning of さらさらした [sarasarashita] is "dry". Example:

余分な皮脂だけ吸収さらさらシフォン肌に(Rakuten).

[Yobun na hishi dake kyuushuu sarasara shifon hada ni].

"Smooth chiffon texture absorbs only excessive sebum".

9. ポロポロ [poroporo] has the following meanings: "peel off”, "roll down"; "fall off"; "dry"; "like a rain". Example:

くすみポロポロ(ROSETTE).

[Kusumi poroporo].

"Peeling gel".

10. つるつる [tsurutsuru] with the particle の [no] has the meaning "smooth", "plane"; "shining". And the meanings of つるつるした [tsurutsurushita] is "slippery"; "smooth", "plane"; "shining” and "oily, fat". Example:

角質つるつるこするジェル(Ibidem).

[Kakushitsu tsurutsuru kosuru jeru].

“Collagen gel scrub providing smoothness".

11.もりもり [morimori] has the meanings "with inspiration", "with pleasure", "with taste"; "taste"; "swollen"; "convex"; "google”. Example:

もりもり寿し(るるぶ金沢 能登 加賀温泉郷: 139).

[Morimori zushi].

"Appetizing Sushi”.

As it can be seen from the examples given, to translate the Japanese onomatopoeia we have involved words of a foreign language which possess the corresponding stylistic colouring, what brings them closer to the original.

\section{Group of onomatopoeia stylized as gitaig}

According to A. Podshibyakina (Podshibyakina, 2003), in the field of Japanese advertising such a phenomenon as stylization of words as gitaigo exists; these new words are formed by reduplication of a whole word, as well as of a part of a word. Having analyzed the chosen ad material, we have established that this is a truly widespread way of creating new onomatopoeia, which, eventually, are gaining popularity in Japanese society. Let us illustrate such stylization of words as gitaigo and the ways of their translations:

1. ひもひも [himohimo]. It is created by reduplicating the word ひも [himo] (lace; tape, string). Example:

$$
\text { ひもひもキャンディ (Kracie). }
$$


[Himohimo kyandi].

"Candy-laces".

Translation of words stylized as gitaigo, causes a translator the greatest difficulty. The repetitive words, of which these onomatopoeia representing a concept mimetically and performatively rather than referentially, are composed, in most European languages are translated as adjectives, adverbs, participle and others but most often they are translated descriptively, in the way which is most appropriate in a given context. For example, consider the onomatopoeia mogimogi:

2. もぎもぎ[mogimogi]. It is created by the root reduplication of the word も ぎる [mogiru] (pick, pluck). Example of the advertisement:

もぎもぎフルーツグミ(Meiji).

[Mogimogi furuutsugumi].

"Chewing fruit to be picked" (see Fig. 4).

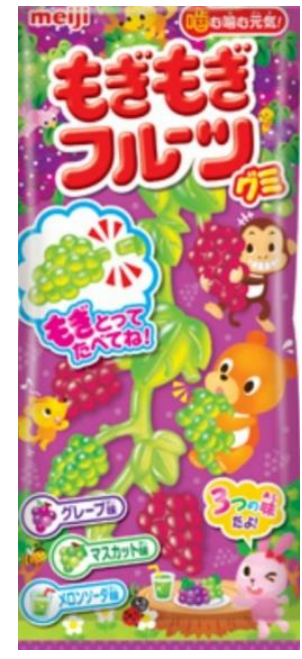

Figure 4. Meiji

It should be noted that to choose a correct counterpart when translating the advertisements of Japanese sweets, you need to know certain nuances. One of the trends of Japanese culture is the manufacture of sweets that children can play with. This is quite unusual for European culture. However, in Japan, this is a common case when candy is a toy. To translate the illustrated examples of advertising correctly, we have to treat the sweets as a toy.

3. つぶつぶ [tsubutsubu]. It is created by reduplicating the word 粒 [tsubu] (grain, drop). Example:

・感も楽しいチョコレート。中には、つぶつぶチョコをいっぱい詰て います(Rakuten).

[Shokkan mo tanoshii chokoreeto. Naka ni wa, tsubutsubu choko wo ippai tsumete imasu].

"Chocolate with a pleasant taste. The middle is full of chocolate seeds".

4. まぜまぜ [mazemaze]. It is created by the root reduplication of the word 混ぜる [mazeru] (mix, admix). Example: 
まぜまぜミックスガム(Amazon).

[Mazemaze mikkusugamu].

"A mix of chewing gums".

Summing up, on the basis of their reduplication structure, the words formed by means of stylization as gitaigo, which represent a concept mimetically and performatively rather than referentially, can be attributed to the onomatopoeic vocabulary of the Japanese language. The only possible way of an adequate translation of their semantics is, quite often, only a descriptive method with the use of several corresponding synonymous words of a foreign language - verbs, adjectives, adverbs, participles, etc.

\section{Group of onomatopoeia with doubling of consonants}

The reduplication of consonants is often used in the onomatopoeia of Japanese advertising texts to enhance its expressiveness and the descriptive effect.

1. すっきり [sukkiri]. The translation of すっきりする is “feel relief”; “feel good”. すっきりした [sukkirishita] has the meaning "clear, bright, straight”; "refreshed". The meaning of すっきりしない is "gloomy”. Example:

ブルブル振動で鼻を刺激。すっきり美鼻(Taobao).

[Buruburu shindou de hana o shigeki. Sukkiri bihana].

"With vibration oscillations, they change a nose. The straight, beautiful nose".

This example has already been presented concerning the onomatopoeia with root reduplication buruburu, but this is the usual situation when several onomatopoeias are present in the same advertising.

2. しっとり [shittori]. しっとりした [shittorishita] is used in meaning "moisturized, wet"; “calm". Example:

ふわふわしっとり新ファンデーションエクサージュ (Ameba).

[Fuwafuwa shittori shin fandeeshon ekusaaju].

"A light moisturizing new base for make-up "EXAGE".

Here we have the same situation when in the same advertising there are several onomatopoeias (fuwafuwa and shittori).

3. さっぱり [sappari] has meaning "not a bit, not in the least"; "in no case"; “completely, entirely, wholly". さっぱりした (sapparishita) has such meanings "clean"; "neat"; “clear"; "frank”, “sincere"; "simple". The unit さっぱりする [sapparisuru] has meaning "feel rejuvenated"; "feel good"; "feel relief". Example:

$$
\text { さっぱりタイプ(ROSETTE). }
$$

[Sappari taipu].

"Cleaning type".

4. ビっくり [jikkuri] can be used with the particle と [to] and has meaning "slowly, unhurriedly"; "carefully, neatly"; "thoroughly, as it should". Example:

炭火でじっくり引き出す食材本来の旨みを堪能 [るるぶ金沢 能登 加賀温泉郷: 46].

[Sumibi de jikkuri hikidasu shokuzai honrai no umami wo tannou].

"Enjoy the taste of natural products that are neatly taken off the fire".

It should be noted that in the translation of Japanese onomatopoeia, especially gitaigo, as well as for the conveying the emotions of a speaker with an impressive variety of their connotative shades, we face a problem of the lack of lexical 
equivalents for the corresponding translation of Japanese onomatopoeia into other languages and the only possible way of an adequate conveying their semantics quite often is only a descriptive method with the use of several corresponding foreign synonymous words, as well as the method of metaphorical transformations when we transfer not a very name with its direct meaning but we transfer a conceptual structure activated by a certain word in the mind of a native speaker due to the relationship of a given word with a given conceptual structure.

\section{Conclusions}

In this paper, the structural and semantic features of the Japanese onomatopoeic vocabulary and peculiarities of its use in modern Japanese advertising as well as ways of its accurate translation have been analyzed.

Advertising texts of three categories have undergone the analysis: food products (namely sweets), cosmetics, and equipment. The onomatopoeic words used in these texts have been classified according to the structural means of their forming: root (word) reduplication, consonant doubling, and stylization as gitaigo. The complex application of methods of lexical-semantic and structural analysis allowed us to draw the following conclusion regarding the onomatopoeia used in these materials. The choice of onomatopoetic vocabulary for writing Japanese advertising texts is not accidental. The root reduplication, which greatly enhances the imagery and metaphoric nature of these words, contributes to the fact that onomatopoeia meets the best the objectives of advertising: to formulate clearly and concisely, accentuate, cause the desired reaction from the consumer. That is why, it is so widely used, practically for any goods and services, as one of the most important factors in attracting customers.

In advertising texts one of the characteristic features of the Japanese onomatopoeia is used - the presence in a single lexeme of several elements of meaning (semes). The more common semes two sememes have, the closer relationship between these sememes is. Depending on the degree of semantic correlation of derivative meanings with the origin, we distinguish 1) functional polysemy, when a word in all its meanings maintains a connection with the traditional referent, i.e., it does not lose its taxonomic belonging inherent in its original meaning; and it denotes the same concept, the specification and expansion of which occurs in the language; 2) conceptual polysemy, when the lexical-semantic variant of the word is characterized by a weak degree of semantic bond and denotes different concepts, i.e., belonging to different reference spheres.

However, when being translated into other languages, not all of them can be conveyed adequately. Therefore, when we deal with the concept of polysemy of Japanese onomatopoeia, in translation one can only use the meaning that is appropriate in a given context. In the absence of adequate equivalents, the Japanese onomatopoeic vocabulary is translated using semantic transformation and metaphorical transformations. It should be noted that some connotative meanings of onomatopoeia remain a puzzle even for those foreigners who have been studying Japanese for years. 
Having analyzed the onomatopoeic words of the chosen advertisement information, we have come to the conclusion that in this realm of language it is very popular to form new words as stylization as gitaigo. Their translation causes a translator the greatest difficulty. The repetitive words, of which these onomatopoeia are composed, in most European languages are translated as adjectives, adverbs and others, but most often they are translated descriptively, in the way which is most appropriate in a given context.

We can note that in the advertisement of food products the proposals that contain onomatopoeia are usually short; they include a minimum of information and a maximum of effect. All these techniques result in attracting customers' attention. In the case of cosmetics advertising, there are several differences from the previous category. First, the proposals are longer and contain a larger amount of information. Secondly, in the advertisement of the same product, there may be several onomatopoeic words. Thirdly, the circle of onomatopoeic units that can be applied is more limited. When working with the advertisement of cosmetic products, it is important to address to sensory perception. Analyzing the last category of advertising, beauty equipments, we came to the conclusion that the main purpose of this advertisement is to attract attention, and this is achieved also by non-standard methods of advertising, color accents and technology achievements.

The process of formation of onomatopoeia is not the same for different parts of speech. However, this is a topic for further research.

\section{References}

Amanuma, Ya. 「擬音語 - 擬態語 辞典」 1974. The Dictionary of Gion-go and Gitai-go. Tokyo: Tokyo-do.

Asano, Ts. 「擬音語 - 擬態語 辞典」 1985. The Dictionary of Gion-go and Gitai-go. Tokyo: Kadokavashteten.

Atoda, T. and Hoshino, K. 阿刀田 稔子 - 星野 和子「擬音語擬態語使い方 辞典」 1995. The Dictionary of Use of Gion-go and Gitai-go. Tokyo: Sotoqushya.

Chang, A. S. チャン、アンドルー「和英擬態語擬音語分類用 法辞典」 1990. Japanese-English Onomatopoieic Dictionary (Classification Type). Tokyo: Thaisyukan-shoethen.

Dmytruk, Veronoka and Dmytruk, Anna. 2016. "Peculiarities of Usage of Onomatopoeia in Japanese Texts of Advertising Character." Scientific Visnik of Lesia Ukrainka East Europ. Nation. Univ. 5(330): 123-128.

Inose, Hiroko. 2008. "Translating Japanese onomatopoeia and mimetic words." In Anthony Pym \& Alexander Perekrestenko (eds.), Translation research projects 1: 97-116. Taragona: Intercultural Studies Group.

Hinata, Sh. 日向茂男「擬音語擬態語の読本」 1991. Gion-go and Gitaigo: A Bookfor Reading. Tokyo: Shoghakkan.

Kobelianska, Oksana. 2017. Onomatopoeic system of modern Japanese language. Kyiv: Dmitry Burago's Vidavnichy dim.

Korshikova, T. 1987. On the question of the morphological classification of onomatopoetic words of the modern Japanese language. Moscow: Muravei. 
Kozub, S. 2006. "Neologism-creations in modern Japanese terminological vocabulary." Shodoznavstvo 35(36): 30-39.

Liddell, Henry Georgeand and Scott, Robert. 1940. A Greek-English Lexicon. Oxford: Clarendon Press.

Mamontov, Александр. 2002. Cross-cultural analysis (linguistic studies in advertising). Moscov: Izdatelstvo Moskovskoi gumanitarno-socialnoi academii.

Maslov, Yurii. 1987. Introduction to Linguistics. Moscow: Vysshaia Schola.

Osaka, Naoyuki. 1990. "Multidimensional Analysis of Onomatopoeia - A note to make sensory scale from word." Studia phonologica 25-33. Via Kyoto University Research Information Repository.

Podshibyakina, A. 2003. Onomatopoeic lexis in Japanese. Moscow: Muravei.

Tangeit, Mark. 2008. World history of advertisement. Moscow: Alpina Biznes Buks.

Uemura, Susum. 2012. Course of lectures on Japanese history. [Electronic resource]. Kyiv: Taras Shevchenko National University of Kyiv. Access mode: http://www.philology.kiev.ua/php/26/bibl.html.

Yamaguchi，N. 山口 仲美「暮らしのことば擬音・擬態語辞典」 2003. The Dictionary of Colloquial Gion-go and Gitai-go. Tokyo: Kondansa.

\section{Websites}

"Amazon." [Electronic resource]. Access mode: http://www.amazon.co.jp/\%E4\%B8\%B8\%E5\%B7\%9D\%E8\%A3\%BD\%E8\%8F\%9 3\%E6\%98\%9F\%Е3\%81\%AE\%Е3\%82\%AB\%Е3\%83\%ВC\%Е3\%83\%93\%Е3\%82 $\%$ A3\%Е3\%81\%BE\%Е3\%81\%9C\%Е3\%81\%BE\%E3\%81\%9C\%E3\%83\%9F\%Е3\% $83 \% 83 \% \mathrm{E} 3 \% 82 \% \mathrm{AF} \% \mathrm{E} 3 \% 82 \% \mathrm{~B} 9 \% \mathrm{E} 3 \% 82 \%$ AC\%E3\%83\%A0-

$47 \mathrm{~g} \% \mathrm{C} 3 \% 9710 \% \mathrm{E} 8 \% \mathrm{~A} 2 \% 8 \mathrm{~B}-\mathrm{x} / \mathrm{dp} / \mathrm{B} 019 \mathrm{DTDZDM}$. Title from the screen. Date of access: $23 / 04 / 2018$.

"Ameba." [Electronic resource]. Access mode: http://ameblo.jp/garuoku/. Date of access: 08/04/2018.

"Ameba." [Electronic resource]. Access mode: http://ameblo.jp/fsight/entry11622245732.html. Title from the screen. Date of access: 15/03/2018.

"Ameba." [Electronic resource]. Access mode: http://ameblo.jp/albionjp/entry-11584120785.html. Title from the screen. Date of access: 08/03/2018.

"AWAKE." [Electronic resource]. Access mode: http://www.blog.awake.co.jp/article/detail/232895. Title from the screen. Date of access: 08/03/2018.

"BIGLOBE." [Electronic resource]. Access mode: http://kus3.at.webry.info/201307/article_7.html. Title from the screen. Date of access: $15 / 04 / 2018$.

"Heart." [Electronic resource]. Access mode: http://heartltd.jp/product/popular/\%E3\%81\%97\%E3\%82\%93\%E3\%81\%A1\%E3\%82\%83\%E3 \%82\%93\%E3\%81\%B7\%E3\%82\%8A\%E3\%81\%B7\%E3\%82\%8A\%E3\%83\%97\%Е $3 \% 83 \% \mathrm{AA} \% \mathrm{E} 3 \% 83 \% \mathrm{~B} 3 \% \mathrm{EF} \% \mathrm{BC} \% 93 . \mathrm{html}$. Title from the screen. Date of access: $15 / 03 / 2018$.

"Kabaya." [Electronic resource]. Access mode: http://www.kabaya.co.jp/sakupan/. Title from the screen. Date of access: $15 / 03 / 2018$. 
"Kracie." [Electronic resource]. Access mode: http://www.kracie.co.jp/products/puresavon/bodysoap/index.html. Title from the screen. Date of access: 15/03/2018.

"Kracie." [Electronic resource]. Access mode: http://www.kracie.co.jp/products/neruneru/. Title from the screen. Date of access: $15 / 03 / 2018$.

"Kracie." [Electronic resource]. Access mode: http://www.kracie.co.jp/eng/products/popin_n/popin_n/10118268_19786.html. Title from the screen. Date of access: 15/04/2018.

"Kracie." [Electronic resource]. Access mode: http://www.kracie.co.jp/ products/himohimo/. Title from the screen. Date of access: 23/04/2018.

"LOWYA." [Electronic resource]. Access mode: http://www.lowya.com/c/\%E5\%AD\%90\%E4\%BE\%9B\%E7\%94\%A8\%E5\%AE\%B 6\% $5 \% 85 \% \mathrm{~B} 7 / \% \mathrm{E} 3 \% 83 \% \mathrm{~A} 9 \% \mathrm{E} 3 \% 83 \% \mathrm{~B} 3 \% \mathrm{E} 3 \% 83 \% 89 \% \mathrm{E} 3 \% 82 \% \mathrm{BB} \% \mathrm{E} 3 \% 83$ $\% \mathrm{AB} / \mathrm{fh} 01-\mathrm{mz} 003 /$. Title from the screen. Date of access: 18/03/2018.

"Meiji." [Electronic resource]. Access mode: http://catalogp.meiji.co.jp/products/sweets/kids_character/010407/22505.html. Title from the screen. Date of access: 15/03/2018.

"Meiji." [Electronic resource]. Access mode: http://catalogp.meiji.co.jp/products/sweets/kids_character/010407/22505.html. Title from the screen. Date of access: 23/04/2018.

"Pocky." [Electronic resource]. Access mode: http://www.pocky.jp/ products/tsubutsubu/. Title from the screen. Date of access: 23/04/2018.

"Rakuten." [Electronic resource]. Access mode: http://item.rakuten.co. jp/okodepa/1-08-0-000413/. Title from the screen. Date of access: 15/03/2018.

"Rakuten." [Electronic resource]. Access mode: http://item.rakuten.co.jp/rlwaffle/c/0000000164/. Title from the screen. Date of access: 08/03/2018.

"Rakuten." [Electronic resource]. Access mode: http://item.rakuten.co.jp/ rlwaffle/c/0000000164/. Title from the screen. Date of access: 15/03/2018.

"Rakuten." [Electronic resource]. Access mode: http://item.rakuten.co.jp /dagasi/10001535/. Title from the screen. Date of access: 03/04/2018.

"Rakuten." [Electronic resource]. Access mode: http://item.rakuten.co.jp/ fujishop/crunkykids16/.Title from the screen. Date of access: 15/03/2018.

"Taobao." [Electronic resource]. Access mode: https://item.taobao.com/ item.html?id=36742170768. Title from the screen. Date of access: 15/03/2018.

"Rakuten." [Electronic resource]. Access mode: http://item.rakuten.co.jp/oga/m1000h/. Title from the screen. Date of access: 16/03/2018.

"Rakuten." [Electronic resource]. Access mode: http://item.rakuten.co.jp/ kaigo/4971710318890/. Title from the screen. Date of access: 13/03/2018.

"ROSETTE." [Electronic resource]. Access mode: https://rosette.jp/u/brand/rgm_n.php. Title from the screen. Date of access: 08/03/2018. るるぶ金沢 能登 加賀温泉郷. (2016) - Jtbパブリッシング, no 17.

\section{Lexicographical Sources}

Dictionary of iconic expressions in Japanese, edited by Hisao Kakehi, Ikuhiro Tamori, Lawrence Schourup : with the assistance of Leslie James Emerson. 1996. Berlin; New York: Mouton de Gruyter. 
Khiroiuki, Ehava and Kobelyanska, Oksana. 2017. Japanese-Ukrainian Themed Dictionary of Onomatopoeic Vocabulary. Kyiv: Dmytro Burago's Vydavnychyi dim.

Kobelyanska, Oksana and Khiroiuki, Ehava. 2016. Japanese-Ukrainian dictionary of onomatopoeic vocabulary. Kyiv: Dmytro Burago's Vydavnychyi dim.

"Weblio." Japanese-English and Japanese-Japanese thesaurus [Electronic resource]. Access mode: http://www.weblio.jp/. 